\title{
Chest Pain and Alternate Dysphagia
}

\author{
Mosayeb Moradniani ${ }^{1}$, Zaker Salehi $^{2,},{ }^{*}$ Zia Obeidavi ${ }^{1}$
}

1. Department of Internal Medicine, Faculty of Medicine, Lorestan University of Medical Sciences, Khorramabad, Iran

2. Department of Radiation Sciences, Yasuj University of Medical Sciences, Yasuj, Iran

\section{* Corresponding Author:}

Zaker Salehi, PhD

Department of Radiation Sciences, Yasuj University of Medical Sciences, Yasuj, Iran

Tel: +987433235138

Fax: + 987432229816

Email: phyzaker@gmail.com

Received: 07 Jul. 2017

Accepted: 20 Sep. 2017

Please cite this paper as:

Moradniani M, Salehi Z, Obeidavi Z. Chest Pain and Alternate Dysphagia. Middle East J Dig Dis 2017;9:244-245. doi: 10.15171/mejdd.2017.82.

A 67-year-old woman presented to our clinic with 5 years history of intermittent dysphasia. She described dysphasia during the intake of solid food and sometimes with liquid food. She did not note abdominal pain, hematemesis, or melena, but in the past two years, she noted a weight loss of $5 \mathrm{kgs}$. Her medical history was significant only for hypertension, which was controlled by $100 \mathrm{mg}$ daily dose of metoprolol in divided doses. She occasionally took non-steroidal anti-inflammatory drug (NSAID). Physical examination did not reveal any finding.

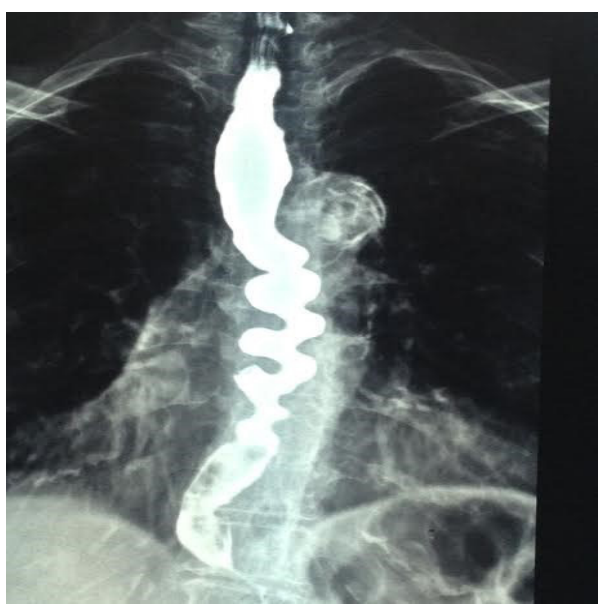

(a)

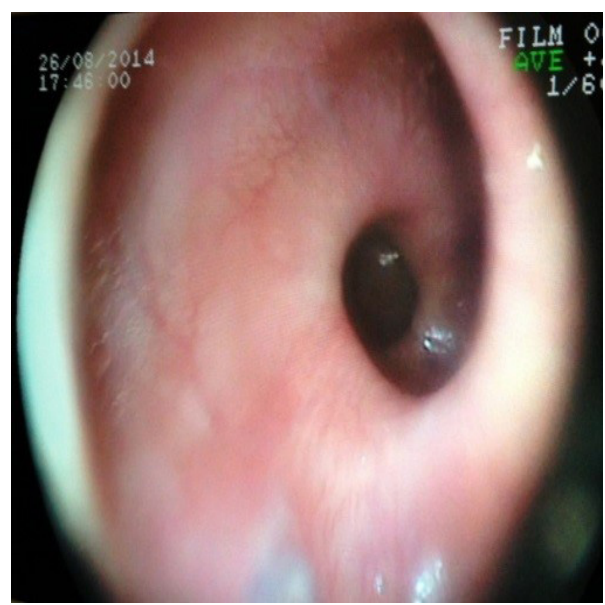

(b)

Fig.1: (a) The patient's radiography with barium shows bottle opener shape, (b) and spiral lumen of the esophagus is seen in the patient's endoscopy. 
What is your diagnosis?

Answer:

Upper endoscopy and barium swallow are shown in figure 1. Endoscopic finding and barium swallow revealed a corkscrew appearance (figure 1.a) together with a pronounced helical configuration of the esophageal lumen (figure 1.b). The patient underwent manometry, which indicated peristaltic contraction in the trunk of the esophagus. The intensity of contractility mostly was more than $180 \mathrm{mmHg}$. Base pressure of the lower esophageal sphincter and its loosening during swallowing was normal. Thus due to lack of simultaneous contractility and normal LES (Lower Esophageal Sphincter) there was no evidence for diffused esophageal spasm. The diagnosis was compatible with nutcracker esophagus.

\section{DISCUSSION}

Nutcracker is considered as the most common symptoms inclusive chest pain and dysphasia in patients receiving manometry due to unknown causes. ${ }^{1}$ The clinical manifestations of nutcracker esophagus included pain in the posterior side of the sternum, dysphagia, heartburn, regurgitation, dyspepsia, cough, and odynophagia ${ }^{2}$ symptoms that mainly are inclusive of chest pain and dysphagia. It is also notable that there is a weak correlation between manometric findings and the clinical manifestations such as chest pain and dysphagia. ${ }^{3,4}$ But it is clear that not all patients with nutcracker esophagus have chest discomfort. The patients with chest pain may have increasing visceral sensitivity. It is shown that when the intensity of the esophageal trunk wave is more than $250 \mathrm{mmHg}$, the risk of chest pain is increased. ${ }^{5,6}$ To treat nutcracker esophagus, 60-90 mg diltiazem four times a day, has been shown effective. ${ }^{7}$ Also trazodone $100-150 \mathrm{mg}$ a day and imipramine $50 \mathrm{mg}$ a day are applicable for chest pain relief in patients with esophageal motility disorder. ${ }^{8,9}$ Our patient was treated with high dose proton pump inhibitors but due to lack of clinical improvement, her treatment was changed to long-acting diltiazem, which led to significant improvement in her overall health.

\section{CONFLICT OF INTEREST}

The authors declare no conflict of interest related to this work.

\section{REFERENCES}

1. Katz PO, Dalton CB, Richter JE, Wu WC, Castell DO. Esophageal testing of patients with noncardiac chest pain or dysphagia. Results of three years' experience with 1161 patients. Annals of internal medicine 1987;106:5937. doi: 10.7326/0003-4819-106-4-593.

2. Silva LF, Lemme EM. [Nutcracker esophagus: clinical evaluation of 97 patients. Arq Gastroenterol 2000;37:21723. doi:10.1590/S0004-28032000000400006.

3. Benjamin SB, Gerhardt DC, Castell DO. High amplitude, peristaltic esophageal contractions associated with chest pain and/or dysphagia. Gastroenterology 1979;77:478-83.

4. Jung KW, Jung HY, Yoon IJ, Kim DH, Chung JW, Oh $\mathrm{HC}$, et al. New diagnostic criteria for nutcracker esophagus using conventional water-perfused manometry: a comparison between nutcracker esophagus with and without gastroesophageal reflux disease. J Gastroenterol Hepatol 2010;25:1239-43. doi: 10.1111/j.14401746.2010.06301.x.

5. Mujica VR, Mudipalli RS, Rao SS. Pathophysiology of chest pain in patients with nutcracker esophagus. Am $J$ Gastroenterol 2001;96:1371-7. doi:10.1111/j.15720241.2001.03791.x.

6. Agrawal A, Hila A, Tutuian R, Mainie I, Castell DO. Clinical relevance of the nutcracker esophagus: suggested revision of criteria for diagnosis. J Clin Gastroenterol 2006;40:504-9.

7. Cattau EL, Jr., Castell DO, Johnson DA, Spurling TJ, Hirszel R, Chobanian SJ, et al. Diltiazem therapy for symptoms associated with nutcracker esophagus. $\mathrm{Am} \mathrm{J}$ Gastroenterol 1991;86:272-6.

8. Cannon RO, Quyyumi AA, Mincemoyer R, Stine AM, Gracely RH, Smith WB, et al. Imipramine in patients with chest pain despite normal coronary angiograms. $N$ Engl J Med 1994;330:1411-7. doi: 10.1056/ NEJM199405193302003.

9. Clouse RE, Lustman PJ, Eckert TC, Ferney DM, Griffith LS. Low-dose trazodone for symptomatic patients with esophageal contraction abnormalities. A double-blind, placebo-controlled trial. Gastroenterology 1987;92:1027-36. 